\title{
CHARACTERIZATION AND DATING OF SALINE GROUNDWATER IN THE DEAD SEA AREA
}

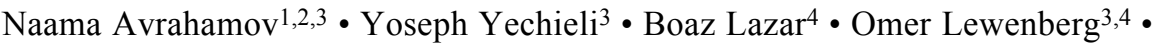 \\ Elisabetta Boaretto ${ }^{5}$ Orit Sivan ${ }^{1,2}$
}

\begin{abstract}
This work presents an attempt to date brines and determine flow rates of hypersaline groundwater in the extremely dynamic system of the Dead Sea (DS), whose level has dropped in the last $30 \mathrm{yr}$ by $\sim 20 \mathrm{~m}$. The processes that affect the carbon species and isotopes of the groundwater in the DS area were quantified in order to estimate their flow rate based on radiocarbon and tritium methods. In contrast to the conservative behavior of most ions in the groundwater, the carbon system parameters indicate additional processes. The dissolved inorganic carbon (DIC) content of most saline groundwater is close to that of the DS, but its stable isotopic composition $\left(\delta^{13} \mathrm{C}_{\mathrm{DIC}}\right)$ is much lower. The chemical composition and carbon isotope mass balance suggest that the low $\delta^{13} \mathrm{C}_{\mathrm{DIC}}$ of the saline groundwater is a result of anaerobic organic matter oxidation by bacterial sulfate reduction (BSR) and methane oxidation. The radiocarbon content $\left({ }^{14} \mathrm{C}_{\mathrm{DIC}}\right)$ of the saline groundwater ranged from $86 \mathrm{pMC}$ (greater than the $\sim 82 \mathrm{pMC}$ value of the DS in the $2000 \mathrm{~s}$ ) to as low as $14 \mathrm{pMC}$. The similarity between the ${ }^{14} \mathrm{C}_{\text {DIC }}$ value and $\mathrm{Na} / \mathrm{Cl}$ ratio of the groundwater at the DS shore and that of the 1980s DS brine indicates that the DS penetrated to the aquifer at that time. The low ${ }^{14} \mathrm{C}_{\mathrm{DIC}}$ values in some of the saline groundwater suggest the existence of ancient brine in the subaquifer.
\end{abstract}

\section{INTRODUCTION}

\section{General}

Radiocarbon activity in dissolved inorganic carbon (DIC) is used as the main dating tool in groundwater systems around the world. However, there is a suite of geochemical processes that affect the DIC and its isotopic composition and should therefore be considered in ${ }^{14} \mathrm{C}_{\text {DIC }}$ age determination of groundwater (Mook 1980). Mixing of different ${ }^{14} \mathrm{C}_{\mathrm{DIC}}$ water bodies is one process that should be taken into account. In a groundwater system with several water bodies of different salinities, the mixing fractions can generally be calculated by conservative species such as the chloride ion. On the other hand, quantification of other DIC sources can be more challenging. In carbonate aquifers, the most prevalent process is dissolution of ${ }^{14} \mathrm{C}$-free ancient $\mathrm{CaCO}_{3}$ (Münnich 1957; Ingerson and Pearson 1964). Organic matter oxidation by various electron acceptors, such as sulfate, adds also DIC to the water with the age of the organic matter (Pearson and White 1967; Pearson and Hanshaw 1970). Methane $\left(\mathrm{CH}_{4}\right)$ oxidation (methanotrophy) in groundwater can also contribute carbon to the DIC pool (Barker et al. 1979) with its age imprint. Besides these sources of DIC, diffusion in stagnant zones (e.g. clays) was shown to significantly affect ${ }^{14} \mathrm{C}$ ages of groundwater (Sanford 1997), as well as isotope exchange.

Few studies have dealt with dating of brines using the ${ }^{14} \mathrm{C}$ method. In addition to the unclear geochemical history of the groundwater, high salinity may have different isotopic exchange kinetics (Wendt 1971); therefore, ${ }^{14} \mathrm{C}$ dating of saline groundwater is more complex. Several studies investigated saline lakes showing that the carbon system in most aquatic environments is controlled mainly by temperature, pressure, and brine salinity, which may reduce the $\mathrm{pH}$ of the system (Druckenmiller and Maroto-Valer 2005).

\footnotetext{
${ }^{1}$ Department of Geological \& Environmental Sciences, Ben Gurion University of the Negev, Beer Sheva 84105, Israel.

${ }^{2}$ Corresponding authors. Email: katzavn@bgu.ac.il; oritsi@bgu.ac.il.

${ }^{3}$ Geological Survey of Israel, Jerusalem 95501, Israel.

${ }^{4}$ Institute of Earth Sciences, Hebrew University, Jerusalem 91904, Israel.

${ }^{5}$ Kimmel Center for Archaeological Science, Weizmann Institute, Rehovot 76100, Israel.
}

C 2010 by the Arizona Board of Regents on behalf of the University of Arizona Proceedings of the 20th International Radiocarbon Conference, edited by A J T Jull RADIOCARBON, Vol 52, Nr 2-3, 2010, p 1123-1140 


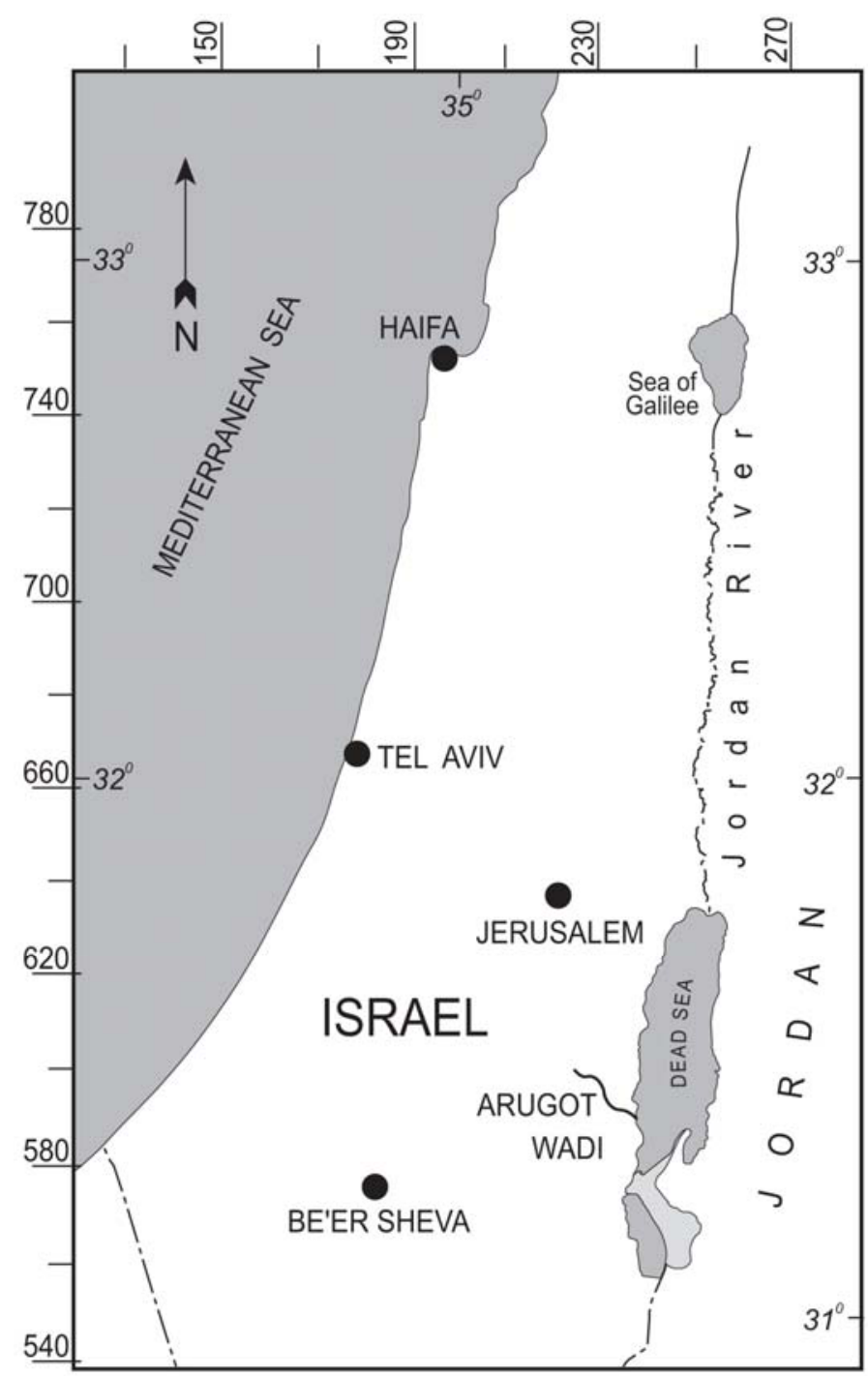

Figure 1 Map of the Dead Sea and location of the research area in Wadi Arugot

The goal of this study was to understand the geochemical processes in the hypersaline groundwater of the coastal Dead Sea (DS) area in order to estimate the ${ }^{14} \mathrm{C}$ ages of groundwater. The geochemical approach was to measure the chemical and carbon isotope composition along a transect adjacent to the DS (groundwater in the Arugot alluvial fan, Figure 1), define the end-members and mixing relations, and quantify the contribution of the different carbon sources to the groundwater system by isotopic mass balance calculations. Beside its application for dating, the carbon system investigation provides a unique signature for different processes (e.g. organic matter oxidation), which are barely reflected by the other ions due to the high ion concentrations. It should be noted that the ${ }^{14} \mathrm{C}$ age of groundwater refers to the time from its recharge into the subsurface and disconnection from the atmospheric $\mathrm{CO}_{2}$ until reaching the sampling point, or the time of the DS water penetration into the aquifer. 


\section{The Carbon Isotope System}

Measurements of $\delta^{13} \mathrm{C}_{\mathrm{DIC}}$ in the DS water column were reported by Nissenbaum and Kaplan (1976), Stiller et al. (1985), Luz et al. (1997), and Barkan et al. (2001). These studies show that the $\delta^{13} C_{\text {DIC }}$ of the DS is mainly controlled by abiotic processes and is strongly influenced by $\mathrm{CO}_{2}$ escape due to the increasing $\mathrm{P}_{\mathrm{CO} 2}$ of the water (Barkan et al. 2001). The ${ }^{14} \mathrm{C}_{\mathrm{DIC}}$ content of the DS and the factors controlling it were investigated by Stiller et al. (1988), Talma et al. (1997), and Belmaker et al. (2007). In the early 1960s, the DS surface water had ${ }^{14} \mathrm{C}_{\text {DIC }}$ values of $\sim 82 \mathrm{pMC}$ (Neev and 1967), increasing up to $107 \mathrm{pMC}$ in 1977 (Talma et al. 1997). The $2003{ }^{14} \mathrm{C}_{\mathrm{DIC}}$ value was $\sim 82 \mathrm{pMC}$, as determined in this work. ${ }^{14} \mathrm{C}$ in the DS is affected by $\mathrm{CO}_{2}$ exchange with the atmosphere and by ${ }^{14} \mathrm{C}_{\mathrm{DIC}}$ contributions from the Jordan River, rain, groundwater, and mountain floods from both sides of the DS. The main processes that affect these components were estimated to be water-rock interaction and the exchange of ${ }^{14} \mathrm{CO}_{2}$ between the water and atmosphere (Belmaker et al. 2007). Chemical and stable isotope investigations of groundwater brines in the DS area were conducted by Bentor (1961), Gat et al. (1969), Starinsky (1974), Fleischer et al. (1977), Vengosh et al. (1991), Yechieli et al. (1996), Stein et al. (1997), and Gavrieli and Stein (2006). The preliminary ${ }^{14} \mathrm{C}_{\mathrm{DIC}}$ data of Yechieli et al. (1996) implied that the percolation of groundwater brines into the sediments took place more than $9000 \mathrm{yr}$ ago. The other studies investigated the origin of the brines, but the carbon parameters and isotopes in the groundwater system have not been fully studied. In addition, estimations of the flow rate of the fresh groundwater and brine groundwater from the west eastward to the DS and the flow rate of brine from the DS toward the fresh-saline water interface (FSI) using radioactive tools have not been conducted and therefore are within the scope of this research.

\section{Hydrogeological Background}

There are 2 main aquifers in the western part of the DS rift, the limestone and dolomite layers of the Judea Group of Upper Cretaceous age and the alluvial aquifer of Quaternary age (Figure 2). This study focused on the alluvial aquifer in order to analyze the interrelation between the DS and the groundwater in the adjacent aquifer, which is the alluvial one (Figure 2). The alluvial aquifer is generally separated from the Cretaceous aquifer by the western marginal faults of the DS rift, which set the Cretaceous limestone rocks of the Judea Group against the Quaternary alluvial rocks. The main freshwater source of the alluvial aquifer is from the Cretaceous aquifer through the noted fault zone. Due to the low precipitation and high evaporation rates in the DS area, only a small amount of water penetrates directly to the alluvial aquifer from floods. The alluvial aquifer is built of sediments of the Lisan and Zeelim formations consisting of alternations of clay and gravel layers. These alternations create a hydrological condition of several subaquifers differing in their water levels, temperature, salinity, and water chemistry (Yechieli 2006). It was postulated that the DS brines are the result of seawater infiltration from the Mediterranean Sea in the Neogene (Neev and Emery 1967; Zak 1967), which underwent high evaporation and several processes of water-rock interaction (Starinsky 1974).

The DS level has dropped by $20 \mathrm{~m}$ in the last $30 \mathrm{yr}$ at an average rate of $80 \mathrm{~cm} / \mathrm{yr}$, and in the last years at an intensified rate of $\sim 1 \mathrm{~m} / \mathrm{yr}$. This sea level decline is a direct result of a negative water budget in the lake (Lensky et al. 2005). As a result, the groundwater level also has been decreasing (Yechieli et al. 1995), shifting the FSI toward the DS and replacing saline groundwater by fresh groundwater (Yechieli et al. 2006). Under these new circumstances, underground salt layers are being exposed to dissolution by groundwater that is unsaturated with respect to halite, and sinkholes are being formed in dozens of sites parallel to the DS shore (Yechieli et al. 2006). These sinkholes create a substantial restriction for infrastructures and development in the DS area. In an attempt to estimate the rate at which the sinkholes are forming, an estimation of the fresh groundwater flow rate is needed; this is one of the motivations for this research. 


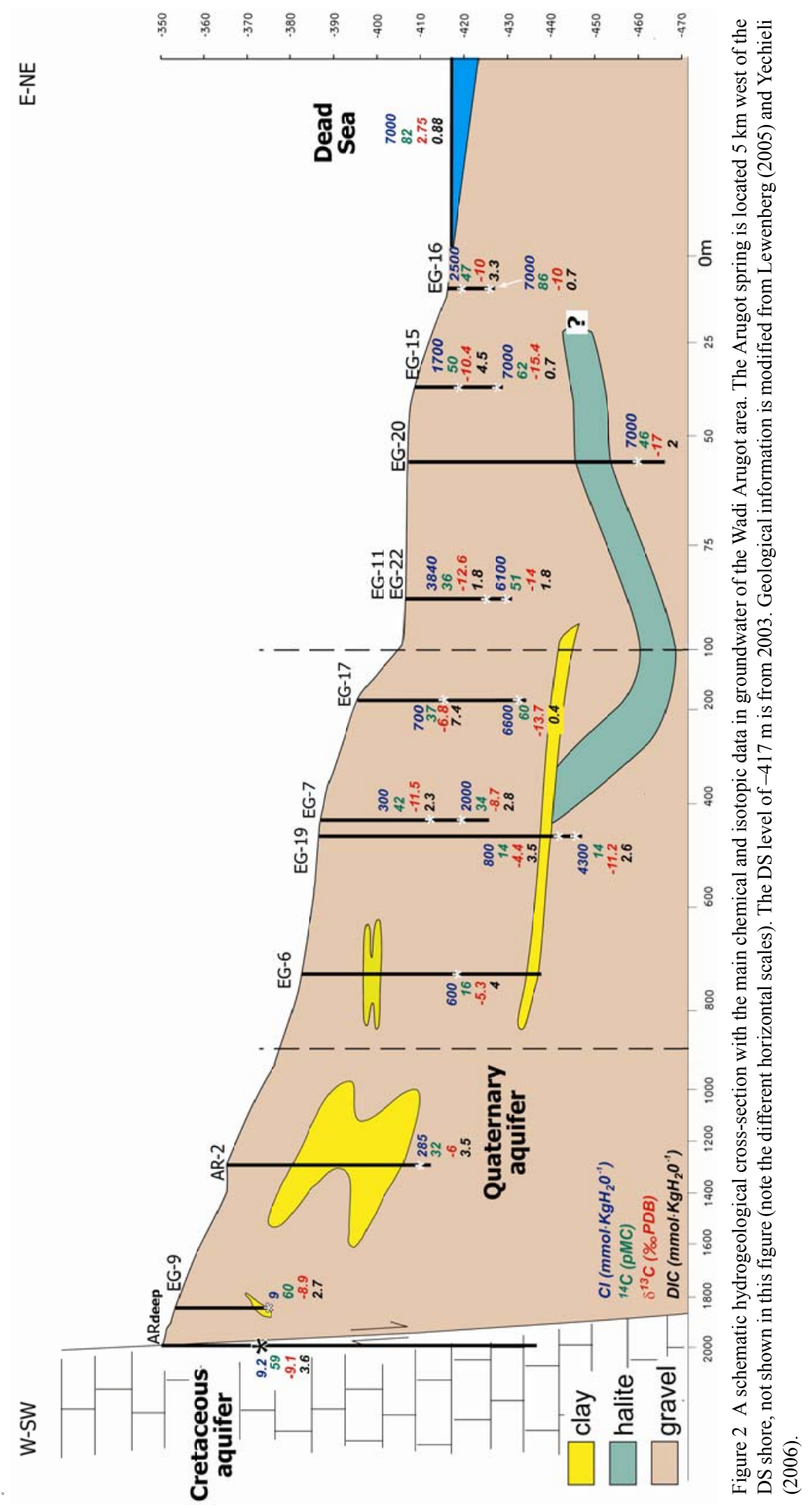


The effect of the decrease in DS levels on groundwater discharge to the DS is debatable. Hydrological simulation of this system showed a rapid hydraulic response of groundwater to the drop of the DS (Kiro 2006). There is still a recirculation of DS water flowing into the aquifer, although the general trend is of groundwater level decrease (Kiro et al. 2008).

\section{METHODS}

\section{Sampling}

Water samples were collected from 2 springs discharging at the head of Wadi Arugot and 14 boreholes drilled along a transect extending from the Arugot springs through the Arugot alluvial fan to the DS (Figure 2). Samples from 1 spring were taken from dripping water (EAR-Arugot spring) and the other spring was sampled from water gushing forth (EASR-secondary Arugot spring). The Wadi Arugot boreholes were sampled with a bailer and a submersible pump.

Conductivity, $\mathrm{pH}$, and temperature were measured in the field. Samples for analysis of major ions and ${ }^{3} \mathrm{H}$ were collected in plastic bottles. Subsamples for total alkalinity (TA), DIC, and carbon isotope analyses were immediately filtered through $0.45-\mu \mathrm{m}$ filters and transferred into $20-\mathrm{mL}$ prepoisoned syringes $\left(\mathrm{HgCl}_{2}\right.$ powder) to avoid bacterial activity. For $\mathrm{CH}_{4}$ and DIC analyses, $5 \mathrm{~mL}$ were transferred from the poisoned syringe to a vacutainer for head space measurements. Due to the vacuum, the gas is naturally extracted from the water to the head space of the vacutainer.

\section{Analytical Methods}

Cations $\left(\mathrm{Na}^{+}, \mathrm{K}^{+}, \mathrm{Ca}^{2+}, \mathrm{Mg}^{2+}, \mathrm{Sr}^{2+}\right)$ were analyzed by ICP-AES (inductively coupled plasma atomic emission spectroscopy) (PerkinElmer, Optima 3000) and chloride by titration with $0.1 \mathrm{~N}^{-\mathrm{ANO}_{3}}$ with a maximum analytical error of $\pm 2 \%$. Chemical compositions were measured at the Geological Survey of Israel (GSI). Total alkalinity (TA) was measured by titration, with $0.01 \mathrm{~N} \mathrm{HCl}$ as a titrant, in a digital titration (Metrohm model 785, Herisau, Switzerland) at the Ben-Gurion University (BGU) lab. The analytical precision from duplicates was $0.03 \mathrm{meq} / \mathrm{L}$. DIC and $\mathrm{CH}_{4}$ concentrations were measured at the BGU by gas chromatograph (GC) (Thermo) equipped with a shincarbonpacked column on the 5-mL water samples that were acidified with phosphoric acid in vacutainers. The $\delta^{13} \mathrm{C}_{\mathrm{CH} 4}$ values were measured also at the $\mathrm{BGU}$ via an isotopic ratio mass spectrometer (IRMS) (DeltaV Advantage, Thermo) equipped with a PreCon interface. The precision of the measurements was $\pm 0.5 \%$ PDB. For the $\delta^{13} \mathrm{C}_{\mathrm{DIC}}$ and ${ }^{14} \mathrm{C}_{\mathrm{DIC}}$ analyses, the inorganic carbon was stripped by phosphoric acid under a high vacuum and purged through a vacuum line at the Weizmann Institute. The $\mathrm{CO}_{2}$ gas was transferred into a glass ampoule and flame-sealed. $\delta^{13} \mathrm{C}$ analysis was conducted on a mass spectrometer (GS-IRMS) with a precision of $\pm 0.03 \%$. The results are given relative to the PDB standard. The $\mathrm{CO}_{2}$ used for ${ }^{14} \mathrm{C}$ analysis was reduced to graphite, and ${ }^{14} \mathrm{C}$ activity was determined using an accelerator mass spectrometer (AMS) at the University of Arizona laboratory. The ${ }^{14} \mathrm{C}$ results are reported as pMC relative to a NBS oxalic acid standard, with a maximum error of $\pm 0.5 \mathrm{pMC}$. Tritium samples were analyzed by a Quantulus scintillation counter device at the German Research Center for Environmental Health $(\mathrm{GmbH})$, Neuherberg, with an error of $0.7 \mathrm{TU}$.

\section{RESULTS}

The full chemical and isotope data of the carbon system are presented in the Appendix and Figure 3. The hydrogeological transect with the values of the main parameters $\left(\mathrm{Cl}^{-},{ }^{14} \mathrm{C}_{\mathrm{DIC}}, \delta^{13} \mathrm{C}_{\mathrm{DIC}}\right.$, and DIC) in the different boreholes is presented in Figure 2. The results of $\mathrm{Na}^{+}$versus $\mathrm{Cl}^{-}$(Figure 3a) indicate that groundwater samples are a mixture of the fresh spring water and the 1980s DS water. The Na-Cl ratio of the DS water was discussed by Gavrieli (1997). A secondary effect is a mixing 


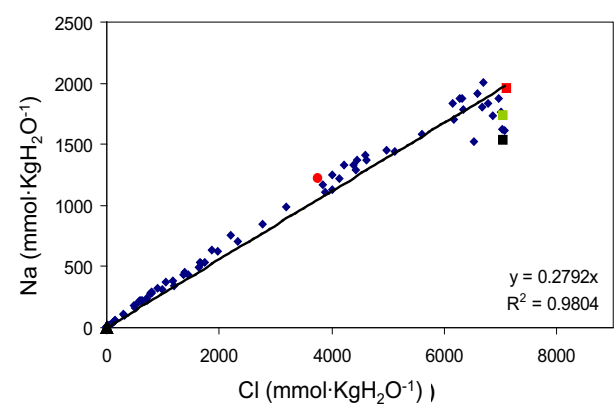

c.

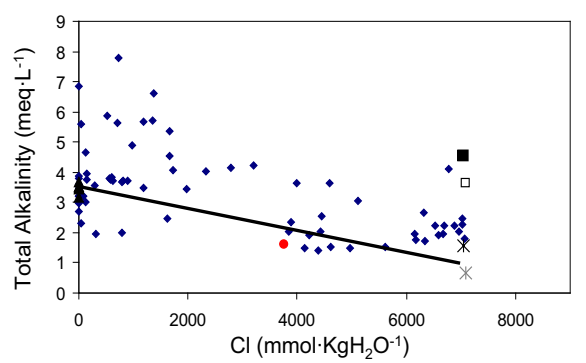

e.

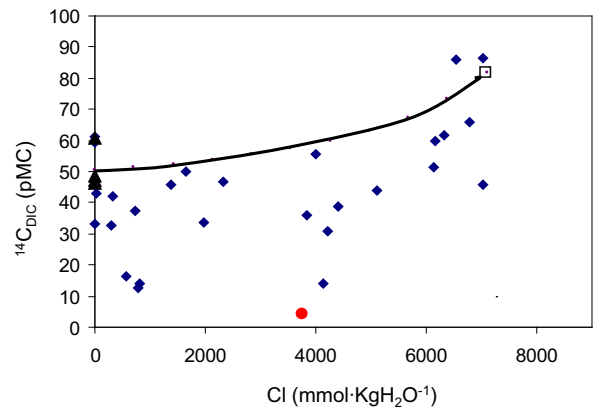

b.

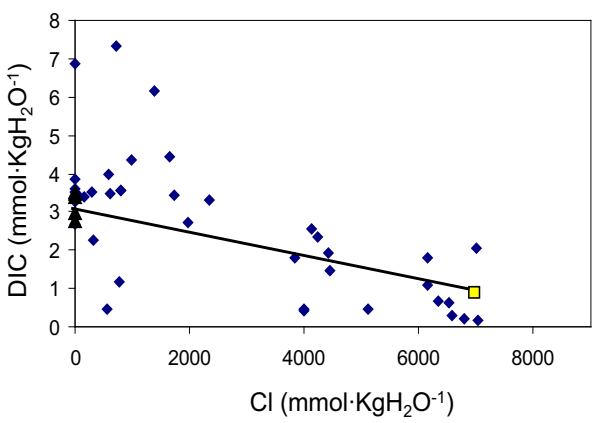

d.

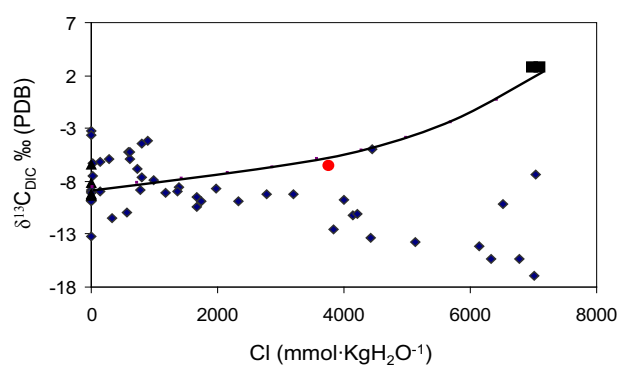

Figure $3 \mathrm{Na}^{+}$, DIC, total alkalinity (TA), $\delta^{13} \mathrm{C}_{\text {DIC }}$, and ${ }^{14} \mathrm{C}_{\text {DIC }}$ versus $\mathrm{Cl}^{-}\left(\mathrm{mmol} \mathrm{kg} \mathrm{H}_{2} \mathrm{O}^{-1}\right)$. The chemical composition indicates that mixing is the main process controlling the major ions, while the non-conservative behavior of the carbon system parameters hints at the presence of additional reactions. In all diagrams, the theoretical mixing line is plotted. In the saline groundwater samples, the borate alkalinity is the dominant component in the TA values.

with the Qedem-Shalem brines, which is above the mixing line. The Qedem-Shalem brines emerge as springs along the DS shores at temperatures of $\sim 40^{\circ} \mathrm{C}$ and have a significantly different chemical composition from that of the DS water, with a salinity of up to $125 \mathrm{~g} \mathrm{Cl} \mathrm{L}^{-1}$ (Gavrieli et al. 2001; Stein et al. 2006). 
The carbon system characteristics are presented in Figures 3 to 5 . In contrast to the conservative behavior of $\mathrm{Na}^{+}$(Figure 3a), the variations of the carbon system parameters versus $\mathrm{Cl}^{-}$indicate a non-conservative behavior (Figure $3 \mathrm{~b}-\mathrm{e}$ ). The lowest DIC values were measured in the vicinity of the DS shore (0.48 mmol DIC $\mathrm{kg} \mathrm{H}_{2} \mathrm{O}^{-1}$ in borehole EG16/11m-EG16 well, $11 \mathrm{~m}$ depth), and the

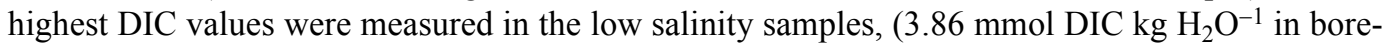
hole AS1). The resulting DIC value of the DS water is $\sim 0.9$ mmol DIC kg H $\mathrm{O}^{-1}$.

The total alkalinity (TA) of the system shows a decreasing trend with salinity increase (Figure 3c). It should be noted that the TA of the Dead Sea (black and empty squares in Figure 3c) is significantly higher than the calculated carbonate alkalinity (gray and black asterisks) due to the large fraction of borate alkalinity (Barkan et al. 2001).

$\delta^{13} \mathrm{C}_{\mathrm{DIC}}$ measurements decrease with the increase of salinity (Figure $3 \mathrm{~d}$ ) from $-8 \%$ to $-4 \%$ in the fresh groundwater and down to $-17 \%$ in the most saline groundwater. The DS values deviate from this trend, having a heavy value of $\sim 2.8 \%$, much higher than any of the groundwater samples. Methane $\left(\mathrm{CH}_{4}\right)$ was found in concentrations of up to $0.7 \mathrm{mmol} \mathrm{kg} \mathrm{H} \mathrm{O}^{-1}$ in most of the saline groundwater with $\delta^{13} \mathrm{C}_{\mathrm{CH} 4}$ values ranging from -40 to $-47 \%$ (Appendix).

The ${ }^{14} \mathrm{C}_{\text {DIC }}$ values in the groundwater samples show a wide range of values between 12 to $86 \mathrm{pMC}$ (Figure 3e). The freshwater samples are characterized by relativity low values, between 42 and 60 pMC. The DS, which is the saline end-member, has ${ }^{14} \mathrm{C}_{\mathrm{DIC}}$ values of $82 \mathrm{pMC}$ (in 2003, Lewenberg 2005 ) to $86 \mathrm{pMC}$ (in the $1980 \mathrm{~s}$, Talma et al. 1997). There are some samples that have ${ }^{14} \mathrm{C}_{\mathrm{DIC}}$ values higher than the present DS, and some saline groundwater samples whose ${ }^{14} \mathrm{C}_{\mathrm{DIC}}$ values are lower than in both end-members of the system. The lowest ${ }^{14} \mathrm{C}$ values (below $20 \mathrm{pMC}$ ) are found in samples of groundwater from the lower subaquifer, measured in borehole EG19.

Tritium was found in most of the groundwater samples in the upper subaquifer with values ranging from 1.1 to $2.9 \mathrm{TU}$. In the lower subaquifer, tritium values were below $1 \mathrm{TU}$.

\section{DISCUSSION}

\section{Alkalinity and DIC}

The non-conservative behavior of the carbon system parameters (Figure 3b-e) indicate that other processes besides mixing take place in the aquifer. While $\mathrm{Na}^{+}$versus $\mathrm{Cl}^{-}$(Figure 3a) shows a linear relationship between the various solutions (fresh and saline), the other parameters deviate from this line. The plot of TA versus $\mathrm{Cl}^{-}$(Figure 3c) may suggest mixing, but the groundwater values are distributed throughout the diagram and indicate a more complicated scenario rather than simple mixing. A better understanding of the relationships that cause the alkalinity deviations from the theoretical mixing line (Figure 3c) can be achieved by plotting the relationship between TA and DIC (Figure 4), which enables identification of the different processes affecting the carbonate system. In general, these processes include decomposition of organic matter and dissolution or precipitation of carbonate minerals as depicted by the Deffeyes diagram (Deffeyes 1965). A slope close to zero between alkalinity and DIC can indicate photosynthetic or aerobic respiration processes, which significantly change the DIC with only a slight change in the alkalinity. A slope of 2 suggests significant precipitation or dissolution of carbonate mineral processes. In the DS area, most groundwater samples fall on a slope of 1 (Figure 4). This could have been the average value of the 2 mentioned processes, as aerobic oxidation of organic carbon releases $\mathrm{CO}_{2}$ that causes dissolution of carbonate minerals. However, due to the low oxygen concentrations in the wells, another scenario for this ratio is anaerobic oxidation of organic carbon by sulfate reduction following the simplified reaction:

$$
2 \mathrm{CH}_{2} \mathrm{O}+\mathrm{SO}_{4}^{-2} \rightarrow \mathrm{H}_{2} \mathrm{~S}+2 \mathrm{HCO}_{3}^{-}
$$




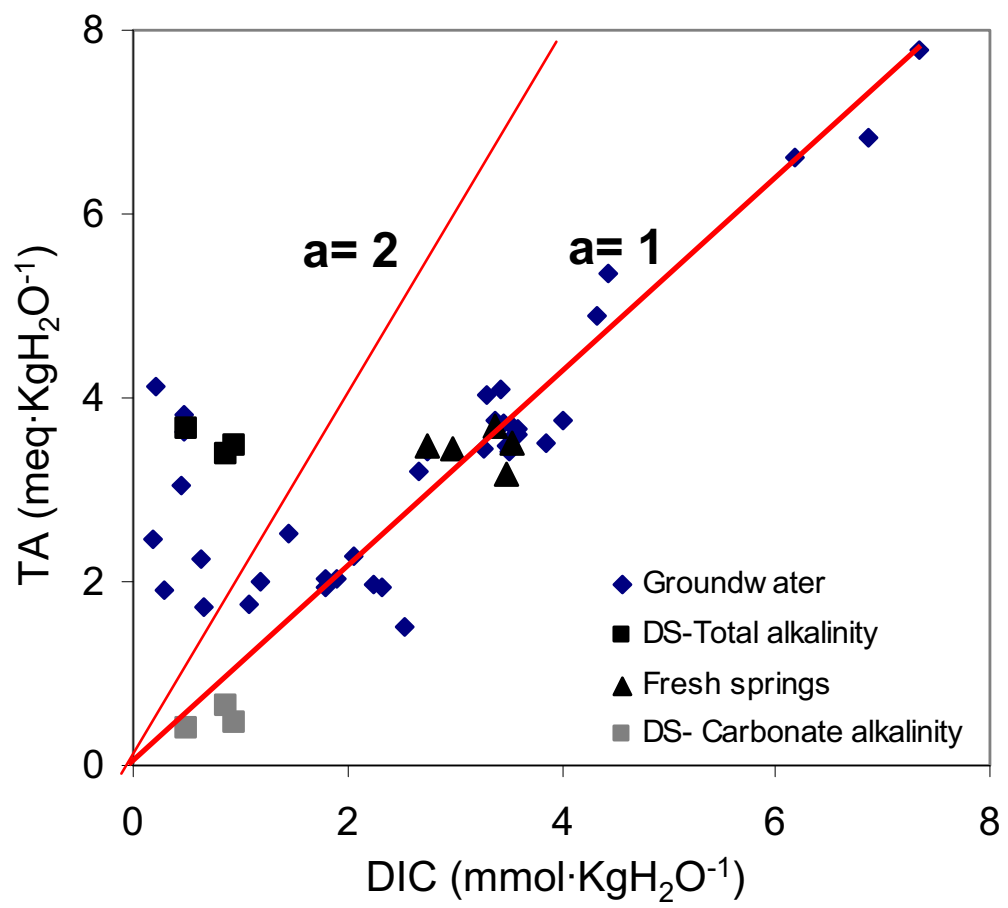

Figure 4 Total alkalinity (TA) versus dissolved inorganic carbon (DIC) in the groundwater samples. Note that many samples fall on a slope line of 1 . A slope line of 2 , which represents dissolution/precipitation of carbonate minerals, is also plotted.

If sulfate is available, even in low concentrations such as in Ca-chloride brines, bacterial sulfate reduction can be a major mechanism of anoxic decomposition of organic matter (Lyons et al. 1994). Indeed, a sulfide scent was detected in some of the boreholes, and heavy $\delta^{34} \mathrm{~S}$ values were measured in the anoxic subsurface brines in the DS area (Gavrieli et al. 2001) and from gypsum precipitation in the ancient DS lakes (Torfstein et al. 2005, 2008). Both aerobic and anaerobic oxidation of organic matter are expected to affect the $\delta^{13} \mathrm{C}_{\mathrm{DIC}}$ values due to the addition of depleted ${ }^{13} \mathrm{C}$ from the organic matter ( -23 to $-25 \%$ in DS sediment; Stiller et al. 1988) with almost no fractionation.

The production of DIC during sulfate reduction depends on the type of organic carbon involved. Oxidation of humic substances, in which the carbon has an overall redox state of 0 (fixed carbon), would follow the reaction shown above. On the other hand, if methane is available, sulfate also can be reduced by it anaerobically (Martens and Berner 1974):

$$
\mathrm{CH}_{4}+\mathrm{SO}_{4}{ }^{2-} \rightarrow \mathrm{HS}^{-}+\mathrm{HCO}_{3}{ }^{-}+\mathrm{H}_{2} \mathrm{O}
$$

The presence of methane in most of the saline groundwater indicates the existence of a rich organic matter reduced system at some depths. Methanogenesis itself is not likely to occur at the depths sampled due to the presence of sulfate and the light $\delta^{13} \mathrm{C}_{\mathrm{DIC}}$ values measured; however, it is probably oxidized at those depths aerobically when oxygen is present or anaerobically by sulfate.

In the case of anaerobic methane oxidation by sulfate, the TA:DIC ratio will be 2:1. Since $\delta^{13} \mathrm{C}_{\mathrm{CH} 4}$ is very light ( -40 to $-47 \%$ in this study) and its oxidation causes only small fractionation (Whiticar et al. 1986; Whiticar 1999), it will have much more impact on $\delta^{13} C_{\text {DIC }}$ values than oxidation of 
organic matter. As shown in the mass balance calculations below, the low observed values of $\delta^{13} \mathrm{C}_{\text {DIC }}$ are explained by oxidation of organic matter, and in some cases also by oxidation of $\mathrm{CH}_{4}$.

Interestingly, in groundwater samples whose DIC values are lower than $2 \mathrm{mmol} \mathrm{kg} \mathrm{H}_{2} \mathrm{O}^{-1}$, the TA values are higher than the general 1:1 ratio for TA:DIC (Figure 4). This water is also characterized

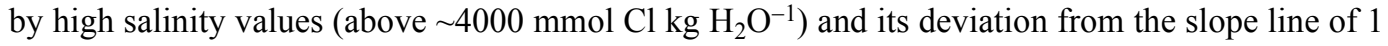
is probably because of the borate alkalinity, which is the main component of TA in the saline samples. A typical value for borate alkalinity in the DS, like in brines, is $\sim 3 \mathrm{mmol} \mathrm{kg} \mathrm{H}_{2} \mathrm{O}^{-1}$ (Schonfeld and Held 1965). This component is conservative (Barkan et al. 2001); therefore, the carbonate alkalinity can be calculated by reducing the borate alkalinity from the TA in the DS samples (gray squares in Figure 4). However, since the borate part in the saline groundwater samples is unknown and its calculation is not trivial (Barkan et al. 2001), the carbonate alkalinity in the saline groundwater was not calculated.

\section{DIC and Carbon Isotope Mass Balance}

Quantification of the processes involving the carbon system was obtained by mass calculations, as shown below for 2 representative groundwater samples. $\delta^{13} \mathrm{C}_{\mathrm{DIC}}$ and ${ }^{14} \mathrm{C}_{\mathrm{DIC}}$ isotopic values of the fresh and saline groundwater (Figure $3 \mathrm{~d}-\mathrm{e}$ ) are affected by the isotopic composition of the different DIC sources (Table 1). There may be also isotope exchange with the solid phase, but its role is expected to be low in the relatively low temperature of groundwater in this study (Thilo and Münnich 1970), and therefore was not considered in this stage. In the following calculations, we assumed that the chemical composition of the groundwater from a specific borehole is a result of mixing between water bodies from 2 nearby boreholes that constitute its 2 end-members. These 2 boreholes were chosen as possible sources according to their salinity and hydrogeological considerations, which include reasonable connectivity to the borehole discussed. From the alluvial aquifer characterizations, the flow direction and hydraulic connections are not always clear. The mixing fraction between the 2 sources was calculated and the expected DIC concentration $\delta^{13} \mathrm{C}_{\mathrm{DIC}}$ and ${ }^{14} \mathrm{C}_{\mathrm{DIC}}$ from mixing was compared to the measured value. The mixing fraction of the more saline end-member $\left(f_{m s}\right)$ in a specific sample was calculated according to the following:

$$
f_{m s}=\frac{C l_{m i x}-C l_{l s}}{C l_{m s}-C l_{l s}}
$$

where $C l_{m i x}$ refers to the measured sample and $C l_{l s}$ and $C l_{m s}$ refer to the less saline and more saline end-members, respectively $\left(f_{l s}=1-f_{m s}\right)$.

Table $1 \delta^{13} \mathrm{C}$ and ${ }^{14} \mathrm{C}$ values of the possible DIC sources in the Dead Sea area.

\begin{tabular}{llrl}
\hline Type of material source & $\delta^{13} \mathrm{C}(\mathrm{PDB})$ & ${ }^{14} \mathrm{C}(\mathrm{pMC})$ & Reference \\
\hline Inorganic carbon in coastal sediments & 0 to $-3 \%$ & & This work \\
near the Dead Sea & & & \\
Inorganic carbon in Dead Sea sediment & 0.2 to $-2.2 \%$ & $5.1-41.2$ & Stiller et al. 1988 \\
Organic carbon in Dead Sea sediment & -23 to $-25 \%$ & $38.2-92.9$ & Stiller et al. 1988 \\
Methane in the groundwater samples & -40 to $-47 \%$ & & This work \\
& 4 samples & & \\
\hline
\end{tabular}

The measured DIC value was compared to the expected DIC value from mixing only. This may be the first clue to production or consumption of DIC in additional processes besides mixing. The $\delta^{13} \mathrm{C}_{\mathrm{DIC}}$ value is then calculated according to the fraction of each component. If the calculated value 
is identical to the measured value, we can assume that the groundwater value is the result of mixing only. In case they do not match, other chemical processes need to be added to the $\delta^{13} \mathrm{C}_{\text {DIC }}$ mass balance. According to the gap between the calculated $\delta^{13} \mathrm{C}_{\mathrm{DIC}}$ and the measured values, we can characterize the additional process, either by a light or a heavy $\delta^{13} \mathrm{C}_{\mathrm{DIC}}$ source. The same fraction values are used in second mass balance equations of ${ }^{14} \mathrm{C}$. Here, we assume that the water from the upper subaquifer is young enough (mostly contain tritium) and therefore ${ }^{14} \mathrm{C}$ decay is not significant. Following are 2 examples that demonstrate the use of mass balance for quantifying these processes (Table 2). It should be mentioned that the mass balance calculations may generate more than 1 solution; thus, the following should be regarded as a rough estimation.

Table 2 Specific data used for the mass balance calculations, Ar2/45m and EG11/19m and their 2 end-members; the more saline and less saline end-members.

\begin{tabular}{|c|c|c|c|c|c|}
\hline & $\begin{array}{l}\text { Borehole } \\
\text { name }\end{array}$ & $\begin{array}{l}\mathrm{Cl} \\
(\mathrm{mmol} \\
\left.\mathrm{kg} \mathrm{H}_{2} \mathrm{O}^{-1}\right)\end{array}$ & $\begin{array}{l}\mathrm{DIC} \\
(\mathrm{mmol} \\
\left.\mathrm{kg} \mathrm{H}_{2} \mathrm{O}^{-1}\right)\end{array}$ & $\begin{array}{l}\delta^{13} \mathrm{C} \\
(\%)\end{array}$ & $\begin{array}{l}{ }^{14} \mathrm{C} \\
(\mathrm{pMC})\end{array}$ \\
\hline \multicolumn{6}{|l|}{ First example } \\
\hline Groundwater sample & Ar2/45m & 285 & 3.53 & -6.0 & 32.5 \\
\hline More saline end-member & EG6/35m & 580 & 4.00 & -5.3 & 16.4 \\
\hline Less saline end-member & EG9/WL & 18 & 3.48 & -7.5 & 43.0 \\
\hline Mixture values by $\mathrm{Cl}$ fraction & & $48 \% \mathrm{EG} 6 / 35 \mathrm{~m}$ & 3.73 & -6.4 & 29.3 \\
\hline \multicolumn{6}{|l|}{ Second example } \\
\hline Groundwater sample & $\mathrm{EG} 22 / 25 \mathrm{~m}$ & 6100 & 1.80 & -14.1 & 51.4 \\
\hline More saline end-member & DS & 7100 & 0.95 & 2.8 & 82.0 \\
\hline Less saline end-member & $\mathrm{EG} 7 / 31 \mathrm{~m}$ & 1980 & 2.74 & -8.7 & 33.7 \\
\hline Mixture values by $\mathrm{Cl}$ & & $80 \% \mathrm{DS}$ & 1.31 & -2 & $\begin{array}{l}44.6 \text { or } \\
72.3^{\mathrm{a}}\end{array}$ \\
\hline
\end{tabular}

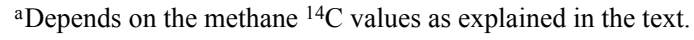

The first example is groundwater from borehole $\mathrm{Ar} 2$ at $45 \mathrm{~m}$ depth. It can be assumed that the water in $\mathrm{Ar} 2$ is a mixture between EG9/WL and EG6/35m (Figure 2). The more saline end-member fraction $\left(f_{\mathrm{ms}}\right)(\mathrm{EG} 6 / 35 \mathrm{~m})$ in $\mathrm{Ar} 2$ groundwater, calculated by salinity $\left(\mathrm{Cl}^{-}\right)$, is:

$$
f_{6 / 35}=\frac{285-18}{580-18}=0.48
$$

Thus, the expected DIC concentration is $(0.48 \times 4.00)+(0.52 \times 3.48)=3.73$. The expected $\delta^{13} \mathrm{C}_{\text {DIC }}$ value is then normalized to the DIC values and calculated according to the fraction of each component using this equation:

$$
f_{m s} \times D I C_{m s} \times \delta^{13} C_{m s}+\left(1-f_{m s}\right) \times D I C_{l s} \times \delta^{13} C_{l s}=D I C_{m i x} \times \delta^{13} C_{m i x}
$$

In this example, according to the data in Table 2, the expected $\delta^{13} \mathrm{C}_{\mathrm{DIC}}$ is

$$
(0.48 \times 4.00 \times-5.3)+(0.52 \times 3.48 \times-7.5)=3.73 X \text {, where } X=-6.4 \% \text { o }
$$

The calculated DIC result is slightly higher than the measured one (3.73 compared to $3.53 \mathrm{mmol}$ DIC $\mathrm{kg} \mathrm{H}_{2} \mathrm{O}^{-1}$ ). Precipitation of $0.20 \mathrm{mmol}$ DIC kg H $\mathrm{H}_{2} \mathrm{O}^{-1}$ in carbonate minerals having a $\delta^{13} \mathrm{C}_{\text {DIC }}$ value of $1.5 \%$ heavier than the original groundwater can explain this small difference. 
We constructed a general $\delta^{13} \mathrm{C}_{\mathrm{DIC}}$ mass balance that calculates the contributions and consumptions of the different possible processes discussed above as follows:

$$
\begin{aligned}
& f_{m s} \times D I C_{m s} \times \delta^{13} C_{m s}+\left(1-f_{m s}\right) \times D I C_{l s} \times \delta^{13} C_{l s}+D I C_{m o} \times \delta^{13} C_{m o}+D I C_{o m o} \times \delta^{13} C_{o m o}+ \\
& D I C_{d i s} \times \delta^{13} C_{d i s}-D I C_{p r} \times \delta^{13} C_{p r}=D I C_{m i x} \times \delta^{13} C_{m i x}
\end{aligned}
$$

where the mo, omo, dis, and $p r$ subscripts denote methane oxidation, organic matter oxidation, carbonate mineral dissolution, and carbonate mineral precipitation processes, respectively. Not all the above possible processes occur in each case, as demonstrated by the Ar2 $\delta^{13} \mathrm{C}_{\mathrm{DIC}}$ mass balance example in which the only additional process is $\mathrm{CaCO}_{3}$ precipitation:

$$
(0.48 \times 4.00 \times-5.3)+(0.52 \times 3.48 \times-7.5)-(0.20 \times(-6.4+1.5))=3.53 X \text {, where } X=-6.4 \% \text { o }
$$

This value is similar to the measured $\delta^{13} \mathrm{C}_{\mathrm{DIC}}(-6 \%)$. The expected ${ }^{14} \mathrm{C}$ value from mixing only is

$$
(0.48 \times 4.00 \times 16.4)+(0.52 \times 3.48 \times 43.0)=3.73 X \text {, where } X=29.3 \mathrm{pMC}
$$

With the carbonate precipitation, the ${ }^{14} \mathrm{C}_{\text {mix }}$ value from the previous equation yields a somewhat higher ${ }^{14} \mathrm{C}_{\mathrm{DIC}}$ :

$$
(0.48 \times 4.00 \times 16.4)+(0.52 \times 3.48 \times 43.0)-(0.20 \times 29.3)=3.53 X, \text { where } X=30.1 \mathrm{pMC}
$$

This value is quite similar to the measured value ( $32.6 \mathrm{pMC})$. These results indicate that mixing is the major process in this case and precipitation is only a minor one.

A more complex mass balance example is from EG22 at $25 \mathrm{~m}$ depth. The best fit for the measured values for this sample was achieved by the 2 end-members: EG7/31m and the DS water. The DS fraction by salinity is

$$
f_{D S}=\frac{6100-1980}{7100-1980}=0.80
$$

According to the calculated fraction, the expected DIC concentration is

$$
(0.8 \times 0.95)+(0.2 \times 2.74)=1.31
$$

This calculated concentration is $0.49 \mathrm{mmol}$ DIC kg H $\mathrm{H}^{-1}$ lower than the measured value of 1.8 mmol DIC kg H $\mathrm{O}^{-1}$.

The $\delta^{13} \mathrm{C}$ mass balance is

$$
(0.8 \times 0.95 \times 2.8)+(0.2 \times 2.74 \times-8.7)=1.31 X, \text { where } X=-2.0 \%
$$

The calculated $\delta^{13} \mathrm{C}_{\mathrm{DIC}}$ is $12.1 \%$ heavier than the measured value (-14.1\%). The process that could be responsible for this difference would be the addition of a DIC source with a light $\delta^{13} \mathrm{C}_{\mathrm{DIC}}$ value. This could be achieved either by organic matter oxidation (about $-24 \%$ ) or methane oxidation (about $-45 \%$ ). In order to obtain the measured $\delta^{13} \mathrm{C}_{\mathrm{DIC}}$ value of $-14.1 \%$ in an organic matter oxidation process, high concentration of DIC is needed, which does not exist in this sample (1.60 compared to the $0.49 \mathrm{mmol}$ DIC $\mathrm{kg} \mathrm{H}_{2} \mathrm{O}^{-1}$ that is missing according to the mixing process alone). This can be shown in the following equation:

$$
(0.8 \times 0.95 \times 2.8)+(0.2 \times 2.74 \times-8.7)+(\underline{\mathbf{1 . 6}} \times-24)=2.97 \times(-14.1 \%)
$$


On the other hand, the methane oxidation process yields the measured $\delta^{13} \mathrm{C}_{\mathrm{DIC}}$ without exceeding the measured DIC concentration:

$$
(0.8 \times 0.95 \times 2.8)+(0.2 \times 2.74 \times-8.7)+(\underline{\mathbf{0 . 5 0}} \times-45)=1.81 \times(-14.1 \%)
$$

The fact that methane was found in this borehole indicates that this could be the dominant process in this case.

The ${ }^{14} \mathrm{C}_{\mathrm{DIC}}$ activity from mixing only is

$$
(0.8 \times 0.95 \times 82)+(0.2 \times 2.74 \times 33.7)=1.31 X, \text { where } X=61.7 \mathrm{pMC}
$$

At this stage, the methane ${ }^{14} \mathrm{C}$ activity is unknown. The following calculations were done, therefore, for 2 possible ${ }^{14} \mathrm{C}_{\mathrm{CH} 4}$ values. If the methane source is old $(0 \mathrm{pMC})$, the equation will be

$$
(0.8 \times 0.95 \times 82.0)+(0.2 \times 2.74 \times 33.7)+(0.50 \times 0)=1.81 X \text {, where } X_{\min }=44.6 \mathrm{pMC}
$$

If the methane is modern $(100 \mathrm{pMC})$, then the equation will be

$$
(0.8 \times 0.95 \times 82.0)+(0.2 \times 2.74 \times 33.7)+(0.5 \times 100.0)=1.81 X, \text { where } X_{\max }=72.3 \mathrm{pMC}
$$

Since the real EG22/25m ${ }^{14} \mathrm{C}$ value is $51.4 \mathrm{pMC}$, these results imply that methane oxidation could be the major process influencing the $\delta^{13} \mathrm{C}_{\mathrm{DIC}}$ and ${ }^{14} \mathrm{C}_{\mathrm{DIC}}$ values, and its ${ }^{14} \mathrm{C}$ activity content is probably low and, therefore, old.

A thermodynamic model for the solubility of methane in brines $\left(0-6 \mathrm{~mol} \mathrm{Cl} \mathrm{kg} \mathrm{H}_{2} \mathrm{O}^{-1}\right)$ was given by Duan et al. (1992). It seems that most of the groundwater samples are unsaturated with respect to methane. The methane source can be both biogenic or thermogenic; further study is planned to examine this.

\section{${ }^{14} \mathrm{C}_{\mathrm{DIC}}$ Evolution}

Figure 5 suggests 5 possible stages in the ${ }^{14} \mathrm{C}_{\mathrm{DIC}}$ evolution of saline groundwater in this part of the DS system. The first stage is implied by the ${ }^{14} \mathrm{C}_{\mathrm{DIC}}$ values of groundwater samples near the DS shore, which are higher than that of the recent DS value (86 pMC in EG16/11m as compared to 82 pMC in the DS; Lewenberg 2005). The EG16 borehole is the closest to the DS; its water has the same composition of major ions as the DS. Therefore, mixing with other water bodies is not reasonable, isolating the transport effect. The first ${ }^{14} \mathrm{C}$ analyses of the DS were conducted during the $1960 \mathrm{~s}$ by Neev and Emery (1967). At that period, the DS had ${ }^{14} \mathrm{C}$ values lower than $86 \mathrm{pMC}$. From the mid-1970s to the mid-1980s, the measured values were above $86 \mathrm{pMC}$, with a maximum measured ${ }^{14} \mathrm{C}_{\mathrm{DIC}}$ value of $107 \mathrm{pMC}$ in 1977 (Talma et al. 1997). Atmospheric ${ }^{14} \mathrm{C}$ values were higher than in the following decades (Levin and Kromer 2004). During the 1980s, the Dead Sea ${ }^{14} \mathrm{C}_{\text {DIC }}$ values decreased, and in 1990 a value of 83 pMC was measured (Talma et al. 1997). Therefore, we can assume that the groundwater in the vicinity of the DS, which is characterized by pMC values of 86 , could have percolated inland at a time of high ${ }^{14} \mathrm{C}$ values. The tritium value of this groundwater sample is also high (2.9 TU; Appendix). The calculated concentration of tritium in 2007 (sampling date), after correcting for radioactive decay, yields a value of $\sim 12 \mathrm{TU}$ for the early $1980 \mathrm{~s}$, which is similar to the measured level at the same time (11.2 TU in 1979; Carmi et al. 1984).

The DS water could have penetrated to the subsurface vertically, when the DS levels were higher than today, covering the area of the borehole, or horizontally westward into the aquifer. If the latter is the dominant component in the flow pattern, then the groundwater flow rate can be calculated. 


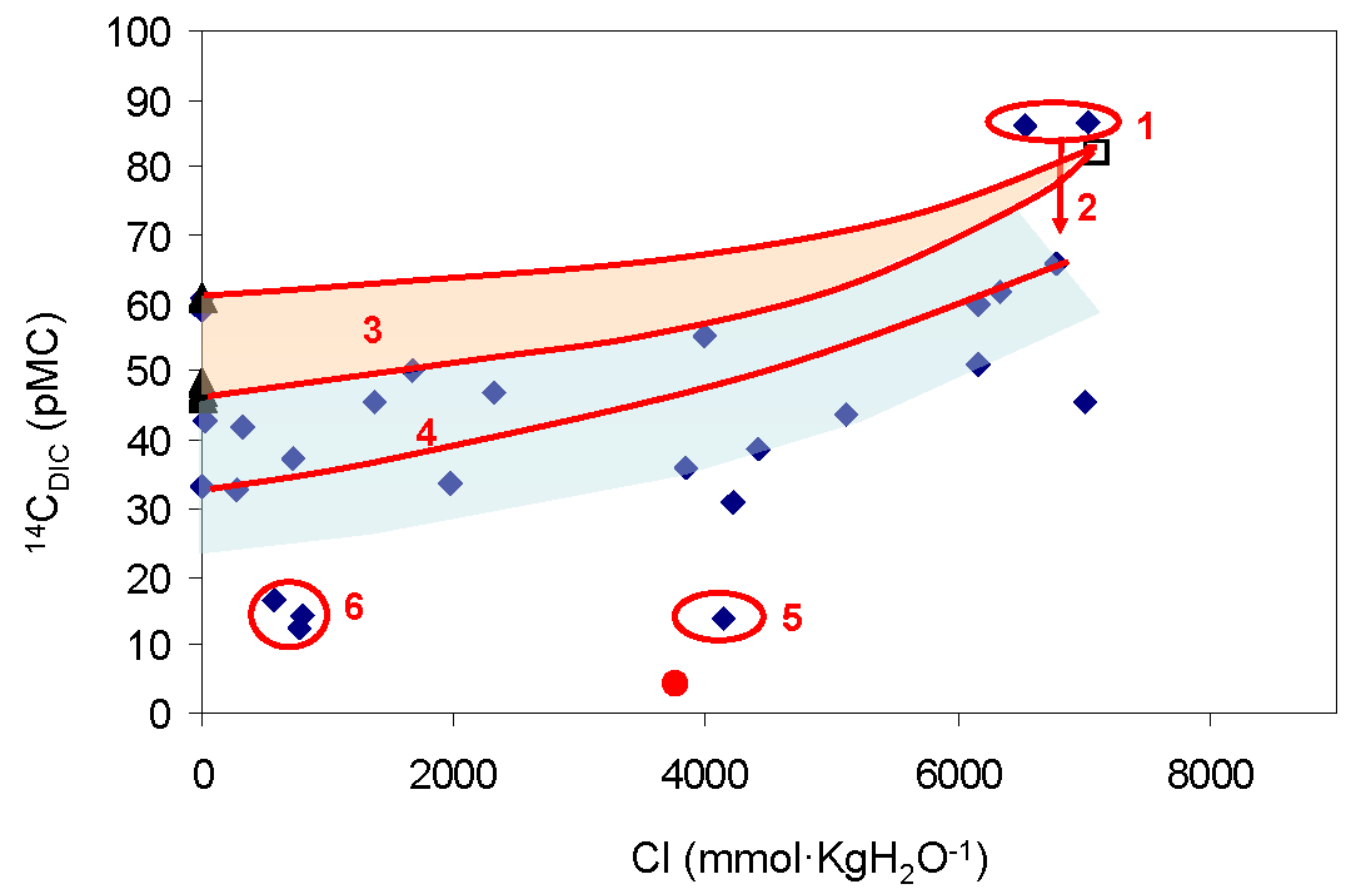

Figure 5 Possible stages of ${ }^{14} \mathrm{C}_{\mathrm{DIC}}$ evolution of saline groundwater in the Dead Sea area

The ${ }^{14} \mathrm{C}_{\text {DIC }}$ value of the groundwater near the DS shore (EG $16 / 11 \mathrm{~m}$ ) is, as mentioned, $86 \mathrm{pMC}$, fitting the 10-yr range ( $\sim 20-30 \mathrm{yr}$ from sampling date, 2003). At the sampling date, this borehole was located $\sim 15 \mathrm{~m}$ from the lake. Therefore, the average flow rate is about $0.5-0.8 \mathrm{~m} / \mathrm{yr}(<15 \mathrm{~m}$ in 20 $30 \mathrm{yr}$ ). This is interesting since it indicates that DS brine still penetrates into the aquifer while the general trend is of decreasing levels. This interpretation is in accord with the results of the hydrological simulation (Kiro et al. 2008).

The second stage has to explain the gap between the ${ }^{14} \mathrm{C}_{\text {DIC }}$ values of the DS and the DS-like groundwater samples (with identical salinity and composition of most ions). This gap can be explained by the low ${ }^{14} \mathrm{C}_{\mathrm{DIC}}$ contribution of old organic matter oxidation from the sediment or methane oxidation (with unknown ${ }^{14} \mathrm{C}_{\mathrm{CH} 4}$ values), as suggested by the mass balance equations. These processes probably do not exist in the DS water before it penetrates into the aquifer.

In the third stage, mixing is expected to occur with the freshwater end-member, as represented by the Arugot spring waters (black triangles, Figure 5). Most of the freshwater values spread over a wide range (46-60 pMC). This range could be the outcome of mixing between 2 freshwater components with different ${ }^{14} \mathrm{C}_{\mathrm{DIC}}$ values, one being old groundwater from the Cretaceous aquifer, owing to relatively low ${ }^{14} \mathrm{C}_{\mathrm{DIC}}$, and the other, recent rain and flood water that penetrated into the aquifer. The flood water is characterized by high ${ }^{14} \mathrm{C}_{\mathrm{DIC}}$ values, determined by the extent of $\mathrm{CO}_{2}$ exchange with the atmosphere (Belmaker et al. 2007). Due to the relatively high DIC values of the spring water compared to those of the DS values, the relative contribution of this end-member is higher, causing the expected mixing line to be lowered a little and not linear. Despite this consideration, the mixing area is almost devoid of samples (area 3 in Figure 5), and the groundwater values are lower than the expected values. 
Line 4 is a mixing line between the fresh groundwater of Arugot 2 borehole (33 pMC) and saline groundwater with the same salinity as the DS (EG 15 borehole, $19 \mathrm{~m}$ depth, $66 \mathrm{pMC}$ ). These 2 groundwater end-members probably underwent several geochemical processes in accordance with the mass balance calculations: calcium carbonate dissolution, organic matter/methane oxidation, and/ or mixing with older water bodies that penetrated into the aquifer in ancient periods. The mixing line (line 4, Figure 5) fits quite well the values of many groundwater samples, though with a wide spread, indicating that these geochemical processes are not equal throughout the groundwater system.

The 2 lower circles in Figure 5 are samples from the lower subaquifer (EG19, marked 5 and 6). Salinity in these depths ranges from $800 \mathrm{mmol} \mathrm{Cl} \mathrm{kg} \mathrm{H}_{2} \mathrm{O}^{-1}$ at $50 \mathrm{~m}$ to $4200 \mathrm{mmol} \mathrm{Cl} \mathrm{kg} \mathrm{H}_{2} \mathrm{O}^{-1}$ at $59 \mathrm{~m}$ depth, and both samples had the same ${ }^{14} \mathrm{C}_{\text {DIC }}$ values $(\sim 14 \mathrm{pMC})$. This means that 2 different water bodies, whose apparent ages are older than several thousand years, exist in the lower subaquifer, one above the other. This implies slow velocity of both the fresh and saline groundwater in this subaquifer. The low ${ }^{3} \mathrm{H}$ concentrations in these samples ( $<1 \mathrm{TU}$; Appendix) support this theory. It can be speculated that these 2 different water bodies represent an ancient FSI zone of one of the precursor lakes, which had a higher water level than the modern DS. In general, the groundwater samples below area 4 probably show the effect of ${ }^{14} \mathrm{C}$ decay and thus have a component of old water.

\section{CONCLUSIONS}

The use of ${ }^{14} \mathrm{C}$ as a sole age determinant in the DS groundwater system is complex and debatable. However, ${ }^{14} \mathrm{C}$ data can be used as a powerful tool for better understanding the processes involving the carbonate system and for yielding a rough timescale. The carbon system parameters give insight into the geochemical processes of the DS groundwater system. The main geochemical processes are probably anaerobic oxidation of organic matter by sulfate reduction and methane oxidation. The methane source and age is not known, nor is the mechanism for its oxidation.

The extremely low ${ }^{14} \mathrm{C}$ values in the lower subaquifer indicate 2 different ancient bodies characterized by different salinities, which could be relics from an ancient hydrological system. The groundwater in the vicinity of the DS shore gives ${ }^{14} \mathrm{C}_{\mathrm{DIC}}$ values of the DS in the $1980 \mathrm{~s}$, which implies that DS water probably penetrated to the aquifer at that time. The determination of the rate flow of the saline groundwater at the FSI can be estimated better after all of the ${ }^{14} \mathrm{C}$ sources are quantified.

\section{ACKNOWLEDGMENTS}

We wish to thank Haim Hemo and Shlomo Ashkenazi for fieldwork and sampling. Chemical analyses were carried out in the laboratory of the Geological Survey with the help of Dina Stiber and Olga Yofe. The graphic help of Nili Almog and Batsheva Cohen is highly appreciated. This research was funded by Ministry of National Infrastructure, grant \#82631201.

\section{REFERENCES}

Barkan E, Luz B, Lazar B. 2001. Dynamics of the carbon dioxide system in the Dead Sea. Geochimica et Cosmochimica Acta 65(3):355-519.

Barker JF, Fritz P, Brown RM. 1979. C-14 measurements in aquifers with $\mathrm{CH}_{4}$. In: Isotope Hydrology 1978. Proceedings Symposium, 19-23 June 1978, Neuherberg, Volume II. Vienna: IAEA. p 661-78.

Belmaker R, Stein M, Yechieli Y, Lazar B. 2007. Control on the radiocarbon reservoir ages in the Dead Sea drainage system and in the last glacial Lake Lisan. $R a$ diocarbon 49(2):969-82.

Bentor YK. 1961. Some geochemical aspects of the Dead Sea and the question of its age. Geochimica et Cosmochimica Acta 25(4):239-60.

Carmi I, Gat JR, Stiller M. 1984. Tritium in the Dead Sea. Earth and Planetary Science Letters 71(2):37789.

Deffeyes KS. 1965. Carbonate equilibria: a graphic and algebraic approach. Limnology and Oceanography 10(3):412-26.

Druckenmiller ML, Maroto-Valer MM. 2005. Carbon sequestration using brine of adjusted $\mathrm{pH}$ to form mineral 
carbonates. Fuel Processing Technology 86(14-15): 1599-614.

Duan Z, Møller N, Greenberg J, Weare JH. 1992. The prediction of methane solubility in natural waters to high ionic strength from 0 to $250^{\circ} \mathrm{C}$ and from 0 to 1600 bar. Geochimica et Cosmochimica Acta 56(4):145160.

Fleischer E, Goldberg M, Gat JR, Magaritz M. 1977. Isotopic composition of formation waters from deep drillings in southern Israel. Geochimica et Cosmochimica Acta 41(4):511-25.

Gat JR, Mazor E, Tzur Y. 1969. The stable isotope composition of mineral waters in the Jordan Rift Valley, Israel. Journal of Hydrology 7(3):334-52.

Gavrieli I. 1997. Halite deposition from the Dead Sea. In: Niemi TM, Ben-Avraham Z, Gat JR, editors. The Dead Sea: The Lake and Its Setting. Oxford: Oxford University Press. p 161-70.

Gavrieli I, Stein M. 2006. The origin and fate of the brines in the Dead Sea basin. In: Enzel Y, Stein M, editors. New Frontiers in Dead Sea Paleoenvironmental Research. Geological Society of America. Special Papers on the Dead Sea 401. p 183-94.

Gavrieli I, Yechieli Y, Halicz L, Spiro B, Bein A, Efron D. 2001. The sulfur system in anoxic subsurface brines and its implication in brine evolutionary pathways: the Ca-chloride brines in the Dead Sea area. Earth and Planetary Science Letters 186(2):199-213.

Ingerson E, Pearson JF. 1964. Estimation of age and rate motion of groundwater by the ${ }^{14} \mathrm{C}$ method. In: Recent Researches in the Fields of the Hydrosphere, Atmosphere and Nuclear Geochemistry. Tokyo: Maruzen. p 263-83.

Kiro Y. 2006. The effect of the Dead Sea level drop in the last fifty years on the groundwater system in the alluvial aquifer and its vicinity [MSc thesis]. Jerusalem: Hebrew University of Jerusalem. In Hebrew.

Kiro Y, Yechieli Y, Lyakhovsky V, Shalev E, Starinsky A. 2008. Time response of the water table and saltwater transition zone to a base level drop. Water Resources Research 44: W12442, doi:10.1029/2007WR006752.

Lensky NG, Dvorkin Y, Lyakhovsky, VL, Gertman I, Gavrieli I. 2005. Water, salt, and energy balances of the Dead Sea. Water Resources Research 41: W12418, doi:10.1029/2005WR004084.

Levin I, Kromer B. 2004. The tropospheric ${ }^{14} \mathrm{CO}_{2}$ levels in mid-latitudes of the Northern Hemisphere. Radiocarbon 46(3):1261-72.

Lewenberg O. 2005. The hydrogeology and geochemistry of groundwater in the alluvial fan of Wadi Arugot, En Gedi reservation [MSc thesis]. Jerusalem: Hebrew University of Jerusalem. In Hebrew.

Luz B, Stiller M, Talma S. 1997. Carbon dynamics in the Dead Sea In: Niemi TM, Ben-Avraham Z, Gat JR, editors. The Dead Sea: The Lake and Its Setting. Oxford: Oxford University Press. p 171-83.

Lyons WB, Hines ME, Last WM, Lent RM. 1994. Sulfate reduction rates in microbial mat of differing chemistries: implication for organic carbon preservation in saline lakes. In: Renaut RW, Last WM, editors. Sedimentology and Geochemistry of Modern and Ancient Saline Lakes. Sedimentary Geology (SEMP). Special Publication 50. p 13-20.

Martens CS, Berner RA. 1974. Methane production in the interstitial waters of sulfate-depleted marine sediments. Science 185(4157):1167-9.

Mook WG. 1980. Carbon-14 in hydrogeological studies. In: Fritz P, Fontes JC, editors. Handbook of Environmental Isotope Geochemistry. Volume 1, Chapter 9. Amsterdam: Elsevier. p 21-47.

Münnich KO. 1957. Messungen des ${ }^{14} \mathrm{C}-$ Gehaltes vom hartem Grundwasser. Naturwissenschaften (44):32-3.

Neev D, Emery KO. 1967. The Dead Sea: Depositional Processes and Environments of Evaporates. Jerusalem: Geological Survey of Israel Bulletin 41. 147 p.

Nissenbaum A, Kaplan IR. 1976. Sulfur and carbon isotopic evidence for biochemical processes in the Dead Sea ecosystem. In: Nriagu JO, editor. Environmental Biogeochemistry. Volume 1. Ann Arbor: Ann Arbor Science Publishers. p 309-25.

Pearson JF, Hanshaw BB. 1970. Sources of dissolved carbonate species in groundwater and their effect on ${ }^{14} \mathrm{C}$ dating. In: Isotope Hydrology 1970. Proceedings Symposium 9-13 March 1970. Vienna: IAEA. p 27186.

Pearson JF, White DE. 1967. C-14 ages and flow rates of water in Carrizo Sand, Atascosa County, TX. Water Resources Research 3(1):251-61.

Sanford WE. 1997. Correcting for diffusion in carbon-14 dating of ground water. Ground Water 35:357-61.

Schonfeld I, Held S. 1965. Spectrochemical methods for determining boron, barium and rubidium in Mediterranean and Dead Sea water. Tel Aviv: Israel Atomic Energy Commission IA-1061.

Starinsky A. 1974. Relationship between Ca-chloride brines and sedimentary rocks in Israel [PhD thesis]. Hebrew University of Jerusalem. In Hebrew.

Stein M, Starinsky A, Katz A, Goldstein SL, Machlus M, Schramm A. 1997. Strontium isotopic, chemical, and sedimentological evidence for the evolution of Lake Lisan and the Dead Sea. Geochimica et Cosmochimica Acta 61(18):3975-92.

Stein M, Lazar B, Stern O, Gavrieli I, Galili E, Yechiel Y. 2006. Paleohydrology and geochemistry of the En Qedem saline spring system. Annual report, Geological Survey of Israel. Publication no. ES-37-2006.

Stiller M, Rounick JS, Shasha S. 1985. Extreme carbonisotope enrichment in evaporating brines. Nature 316(6027):434-5.

Stiller M, Carmi I, Kaufman A. 1988. Organic and inorganic ${ }^{14} \mathrm{C}$ concentrations in the sediments of Lake Kinneret and Dead Sea (Israel) and the factors which control them. Chemical Geology 73(1):63-78.

Talma AS, Vogel JC, Stiller M. 1997. The radiocarbon 
content of the Dead Sea. In: Niemi TM, Ben-Avraham Z, Gat JR, editors. The Dead Sea: The Lake and Its Setting. Oxford: Oxford University Press. p 171-83.

Thilo L, Münnich KO. 1970. Reliability of carbon-14 dating of groundwater: effect on carbonate exchange. In: Isotope Hydrology 1970. Proceedings Symposium 9-13 March 1970. Vienna: IAEA. p 259-70.

Torfstein A, Gavrieli I, Stein M. 2005. The sources and evolution of sulfur in the hypersaline Lake Lisan (paleo-Dead Sea). Earth and Planetary Science Letters 236(1-2):61-77.

Torfstein A, Gavrieli I, Katz A, Kolodny Y, Stein M. 2008. Gypsum as a monitor of the paleo-limnologicalhydrological conditions in Lake Lisan and the Dead Sea. Geochimica et Cosmochimica Acta 72(10):2491509.

Vengosh A, Starinsky A, Kolodny Y, Chivas AR. 1991. Boron isotope geochemistry as a tracer for the evolution of brines and associated hot springs from the Dead Sea, Israel. Geochimica et Cosmochimica Acta (55):1689-95.

Wendt I. 1971. Carbon and oxygen isotope exchange between $\mathrm{HCO}_{3}$ in saline solution and solid $\mathrm{CaCO}_{3}$. Earth and Planetary Science Letters 12(4):439-42.

Whiticar MJ. 1999. Carbon and hydrogen isotope systematics of bacterial formation and oxidation of methane. Chemical Geology 161(1-3):291-314.

Whiticar MJ, Faber E, Schoell M. 1986. Biogenic meth- ane formation in marine and freshwater environments: $\mathrm{CO}_{2}$ reduction versus acetate fermentation-isotopic evidence. Geochimica et Cosmochimica Acta 50(5): 693-709.

Yechieli Y. 2006. Response of groundwater system to change in the Dead Sea level. In: Enzel Y, Agnon A, Stein M, editors. New Frontiers in the Dead Sea Paleoenvironmental Research. Geological Society of America Press. p 113-25.

Yechieli Y, Arad A. 1997. Literature review on mineral waters in the Dead Sea valley. Geological Survey of Israel, Report GSI/29/96, 34 p. In Hebrew.

Yechieli Y, Ronen D, Berkovitz B, Dershovitz WS, Hadad A. 1995. Aquifer characteristics derived from the interaction between water levels of a terminal lake (Dead Sea) and an adjacent aquifer. Water Resources Research 31(4):893-902.

Yechieli Y, Ronen D, Kaufman A. 1996. The source and age of groundwater brines in the Dead Sea area, as deduced from ${ }^{36} \mathrm{Cl}$ and ${ }^{14} \mathrm{C}$. Geochimica et Cosmochimica Acta 60(11):1909-16.

Yechieli Y, Abelson M, Bein A, Crouvi O, Shtivelman V. 2006. Sinkholes "swarms" along the Dead Sea coast: reflection of disturbance of lake and adjacent groundwater systems. Geological Society of America Bulletin 118(9-10):1075-87.

Zak I. 1967. The geology of Mount Sedom [PhD thesis]. The Hebrew University of Jerusalem. In Hebrew.

\section{APPENDIX}

Appendix Carbon system parameters and isotope composition of springs and groundwater from the $\mathrm{DS}$ area. $(\mathrm{NM}=$ not measured; $\mathrm{BDL}=$ below detection limit; $\mathrm{TA}=$ total alkalinity; $\mathrm{DIC}=$ dissolved inorganic carbon; $\mathrm{WL}=$ water level).

\begin{tabular}{|c|c|c|c|c|c|c|c|c|c|c|c|c|c|}
\hline RT- & $\begin{array}{l}\text { Sample } \\
\text { name }\end{array}$ & $\begin{array}{l}\text { Samp- } \\
\text { ling } \\
\text { date } \\
\text { (d.m.y) }\end{array}$ & $\begin{array}{l}\text { Depth } \\
\text { (m) }\end{array}$ & $\begin{array}{l}\mathrm{Cl} \\
(\mathrm{mmol} / \\
\left.\mathrm{kg} \mathrm{H}_{2} \mathrm{O}\right)\end{array}$ & $\begin{array}{l}\mathrm{T} \\
\left({ }^{\circ} \mathrm{C}\right)\end{array}$ & $\mathrm{pH}$ & $\begin{array}{l}\text { TA } \\
\text { (meq/ } \\
\text { L) }\end{array}$ & $\begin{array}{l}\mathrm{CH}_{4} \\
(\mathrm{mmol} / \\
\left.\mathrm{kg} \mathrm{H}_{2} \mathrm{O}\right)\end{array}$ & $\begin{array}{l}\delta^{13} \mathrm{C}_{\mathrm{CH} 4} \\
(\% 0 \\
\mathrm{PDB})\end{array}$ & $\begin{array}{l}\mathrm{DIC} \\
(\mathrm{mmol} / \\
\left.\mathrm{kg} \mathrm{H}_{2} \mathrm{O}\right)\end{array}$ & $\begin{array}{l}{ }^{14} \mathrm{C}_{\text {DIC }} \\
(\mathrm{pMC})\end{array}$ & $\begin{array}{l}\delta^{13} \mathrm{C}_{\mathrm{DIC}} \\
(\% 0 \\
\mathrm{PDB})\end{array}$ & $\begin{array}{l}{ }^{3} \mathrm{H} \\
(\mathrm{TU})\end{array}$ \\
\hline & \multicolumn{13}{|c|}{ Ein Arugot } \\
\hline & EAR & 5.11 .03 & & 3.45 & & & 3.44 & NM & & 2.97 & $47.0 \pm 0.3$ & -9.4 & 1.2 \\
\hline & EAR & 17.3.04 & & 2.57 & & & 3.16 & NM & & 3.48 & $48.4 \pm 0.3$ & -9.2 & 2.8 \\
\hline & EAR & 5.2 .07 & & 3.45 & & & 3.49 & NM & & 2.75 & $60.9 \pm 0.3$ & -6.4 & 2.4 \\
\hline \multirow{2}{*}{5711} & EAR & 5.12 .07 & & 2.83 & & & 3.53 & NM & & 3.53 & $46.3 \pm 0.3$ & -9.4 & 1.0 \\
\hline & EARS & 5.2 .07 & & 4.11 & & & 3.71 & NM & & 3.38 & & -8.1 & \\
\hline \multirow[t]{10}{*}{5599} & EG9 & 7.3.07 & WL & 17.6 & 24 & 6.8 & 3.48 & NM & & 3.49 & $43.0 \pm 0.2$ & -7.5 & \\
\hline & EG9 & 19.11 .07 & WL & 16.5 & & & 3.38 & NM & & & & -6.3 & 1.1 \\
\hline & EG9 & 12.1 .03 & 17.5 & 51 & & & 2.33 & NM & & & & & \\
\hline & EG9 & 12.1 .03 & 18.5 & 6.8 & & & 3.87 & NM & & & & & \\
\hline & EG9 & 12.1 .03 & 21 & 9.0 & & & 3.21 & NM & & 2.66 & $60.0 \pm 0.3$ & -8.9 & 0.7 \\
\hline & EG10 & 7.3 .07 & WL & 3.68 & 22 & 7.0 & 3.46 & 0.05 & & 3.26 & & -8.8 & \\
\hline & EG10 & 19.11 .07 & WL & 5.1 & & & 3.82 & NM & & & & & 1.8 \\
\hline & EG10 & 13.1 .03 & 17.5 & 3.98 & & & 3.21 & NM & & & & & \\
\hline & EG10 & 13.1 .03 & 22 & 3.42 & & & 2.97 & NM & & & & & \\
\hline & EG10 & 7.3.07 & 21 & 151 & 22 & 7.0 & 3.76 & 0.07 & & 3.38 & & -9.0 & \\
\hline
\end{tabular}


Appendix Carbon system parameters and isotope composition of springs and groundwater from the DS area. $(\mathrm{NM}=$ not measured; $\mathrm{BDL}=$ below detection limit; $\mathrm{TA}=$ total alkalinity; $\mathrm{DIC}=$ dissolved inorganic carbon; WL= water level). (Continued)

\begin{tabular}{|c|c|c|c|c|c|c|c|c|c|c|c|c|c|}
\hline RT- & $\begin{array}{l}\text { Sample } \\
\text { name }\end{array}$ & $\begin{array}{l}\text { Samp- } \\
\text { ling } \\
\text { date } \\
\text { (d.m.y) }\end{array}$ & $\begin{array}{l}\text { Depth } \\
\text { (m) }\end{array}$ & $\begin{array}{l}\mathrm{Cl} \\
(\mathrm{mmol} / \\
\left.\mathrm{kg} \mathrm{H}_{2} \mathrm{O}\right)\end{array}$ & $\begin{array}{l}\mathrm{T} \\
\left({ }^{\circ} \mathrm{C}\right)\end{array}$ & $\mathrm{pH}$ & $\begin{array}{l}\text { TA } \\
\text { (meq/ } \\
\text { L) }\end{array}$ & $\begin{array}{l}\mathrm{CH}_{4} \\
(\mathrm{mmol} / \\
\left.\mathrm{kg} \mathrm{H}_{2} \mathrm{O}\right)\end{array}$ & $\begin{array}{l}\delta^{13} \mathrm{C}_{\mathrm{CH} 4} \\
(\% 0 \\
\text { PDB })\end{array}$ & $\begin{array}{l}\mathrm{DIC} \\
(\mathrm{mmol} / \\
\left.\mathrm{kg} \mathrm{H}_{2} \mathrm{O}\right)\end{array}$ & $\begin{array}{l}{ }^{{ }^{14}} \mathrm{C}_{\mathrm{DIC}} \\
(\mathrm{pMC})\end{array}$ & $\begin{array}{l}\delta^{13} \mathrm{C}_{\mathrm{DIC}} \\
(\%) \\
\mathrm{PDB})\end{array}$ & $\begin{array}{l}{ }^{3} \mathrm{H} \\
(\mathrm{TU})\end{array}$ \\
\hline \multirow[t]{6}{*}{5595} & AR2 & 7.3.07 & WL & 3.82 & 29 & 6.3 & 6.86 & 0.06 & & 6.86 & $32.9 \pm 0.2$ & -3.7 & 4.2 \\
\hline & AR2 & 9.12 .02 & 26.5 & 4.46 & & & 2.71 & NM & & & & & \\
\hline & AR2 & 12.1 .03 & 36.2 & 39.5 & & & 5.60 & NM & & & & & \\
\hline & AR2 & 12.1 .03 & 38 & 10.3 & & & 3.41 & NM & & 3.51 & $61.0 \pm 0.3$ & -13.2 & 3.0 \\
\hline & AR2 & 14.1 .03 & 42 & 133 & & & 3.01 & NM & & & & & \\
\hline & AR2 & 15.1 .03 & 45 & 123 & & & 4.66 & NM & & & & & \\
\hline \multirow[t]{3}{*}{5600} & AR2 & 7.3.07 & 45 & 285 & 29 & 6.1 & 3.56 & 0.70 & & 3.53 & $32.5 \pm 0.2$ & -6.0 & \\
\hline & AR2 & 26.11 .07 & 45 & 151 & 31 & 6.9 & 3.94 & 0.58 & & & & -6.2 & 1.7 \\
\hline & $\mathrm{AR}$ & 22.12 .08 & 45 & & & & & 0.36 & -46.7 & & & & \\
\hline 5712 & Ardeep & 19.11.07 & & 9.2 & 25 & 7.2 & 3.59 & NM & & 3.59 & $59.1 \pm 0.3$ & -9.1 & 1.1 \\
\hline \multirow[t]{2}{*}{5592} & ARS1 & 10.1 .07 & & 4.31 & 17 & 7.9 & 3.51 & NM & & 3.86 & $73.7 \pm 0.3$ & -9.9 & 1.3 \\
\hline & EG 6 & 16.1 .07 & WL & 560 & 30.2 & 7.55 & 3.81 & 0.00 & & 0.46 & & -11.0 & \\
\hline \multirow[t]{4}{*}{5601} & EG 6 & 7.3.07 & 35 & 580 & 33 & 6.01 & 3.75 & 0.31 & & 4.00 & $16.4 \pm 0.2$ & -5.3 & \\
\hline & EG 6 & 26.11 .07 & 35 & 610 & 29.5 & 6.56 & 3.81 & 0.20 & & & & -5.9 & 1.1 \\
\hline & EG 6 & 16.1 .07 & 40 & 620 & 29.2 & 6.91 & 3.73 & 0.00 & & 3.47 & & -5.3 & \\
\hline & EG 19 & 16.1 .07 & WL & 800 & 28 & 6.6 & 3.67 & NM & & 3.58 & & -7.6 & \\
\hline \multirow[t]{4}{*}{5603} & EG19 & 7.3 .07 & 50 & 800 & 28 & 6.0 & 3.70 & 0.29 & & 3.54 & $14.2 \pm 0.1$ & -4.4 & \\
\hline & EG 19 & 19.11 .07 & 50 & 900 & 28 & 6.4 & 3.73 & 0.08 & & & & -4.2 & 1.0 \\
\hline & EG19 & 25.8 .04 & 50 & 780 & & & 2.00 & NM & & 1.18 & 12.6 & -8.8 & \\
\hline & EG19 & 18.10 .04 & 58 & 4000 & & & & NM & & 0.43 & & & \\
\hline \multirow[t]{7}{*}{5605} & EG19 & 7.3 .07 & 59 & 4137 & & & & 0.13 & & 2.54 & $13.9 \pm 0.1$ & -11.2 & \\
\hline & EG 19 & 19.11 .07 & 59 & 4975 & 30 & 5.7 & 1.43 & 0.20 & & & & & $<1.1$ \\
\hline & EG 7 & 26.11 .07 & WL & 980 & & & 4.88 & NM & & 4.34 & & -7.9 & 1.5 \\
\hline & EG 7 & 16.1 .07 & WL & 710 & 29 & 6.6 & 5.61 & 0.20 & & & & & \\
\hline & EG7 & 29.12 .02 & $26 a$ & 79 & & & 3.21 & NM & & & & & \\
\hline & EG7 & 7.7 .03 & $26 b$ & 510 & & & 5.86 & NM & & & & & \\
\hline & EG7 & 25.8 .04 & 26.81 & 319 & & & 1.96 & NM & & 2.26 & 42.1 & -11.5 & 0.7 \\
\hline \multirow[t]{3}{*}{5607} & EG 7 & 16.1 .07 & 31 & 1980 & 28 & 5.7 & 3.40 & 0.19 & & 2.74 & $33.7 \pm 0.2$ & -8.7 & \\
\hline & EG7 & 29.12 .02 & $33 a$ & 4380 & & & 1.40 & NM & & & & & \\
\hline & EG7 & 7.7 .03 & $33 b$ & 4220 & & & 1.93 & NM & & 2.34 & $30.8 \pm 0.2$ & -11.1 & 1.1 \\
\hline \multirow[t]{2}{*}{5608} & EG17 & 7.3.07 & WL & 720 & 28 & 6.3 & 7.79 & 0.10 & & 7.33 & $37.4 \pm 0.2$ & -6.8 & \\
\hline & EG17 & 19.11 .07 & WL & 1180 & 25 & 5.8 & 5.65 & 0.27 & & & & -9.1 & 1.5 \\
\hline \multirow[t]{2}{*}{5609} & EG17 & 10.1 .07 & 37 & 6600 & 26 & 5.8 & 1.59 & NM & & 0.30 & $59.3 \pm 0.3$ & & 2.1 \\
\hline & EG17 & 19.11 .07 & 37 & 6700 & & & 1.85 & NM & -45.6 & & & & \\
\hline \multirow[t]{9}{*}{5610} & EG11 & 16.1 .07 & WL & 1380 & 27 & 6.0 & 6.59 & 0.02 & & 6.17 & $45.7 \pm 0.2$ & -8.5 & \\
\hline & EG11 & 19.11 .07 & WL & 1360 & & & 5.64 & 0.03 & & & & -9.0 & 1.4 \\
\hline & EG11 & 15.1 .03 & $13 a$ & 1190 & & & 3.47 & NM & & & & & \\
\hline & EG11 & 15.1 .03 & $13 b$ & 1630 & & & 2.47 & NM & & & & & \\
\hline & EG11 & 7.7.03 & $13 \mathrm{c}$ & 4420 & & & 2.04 & NM & & 1.91 & $38.8 \pm 0.3$ & -13.4 & 1.5 \\
\hline & EG11 & 15.1 .03 & 13.5 & 3880 & & & 2.35 & NM & & & & & \\
\hline & EG11 & 15.1 .03 & 16 & 4620 & & & 1.51 & NM & & & & & \\
\hline & EG11 & 15.1 .03 & 18.5 & 5600 & & & 1.53 & NM & & & & & \\
\hline & EG11 & 7.3.07 & 19 be & 4450 & 27 & 5.6 & 2.47 & 0.12 & & 1.46 & & -5.0 & \\
\hline \multirow[t]{4}{*}{5611} & EG11 & 7.3.07 & 19 af & 3840 & 28 & 5.5 & 1.94 & 0.12 & & 1.79 & $35.8 \pm 0.2$ & -12.6 & \\
\hline & EG11 & 26.11 .07 & 19 & 3200 & 28 & 6.1 & 4.09 & 0.27 & & & & -9.2 & 1.4 \\
\hline & EG11 & 25.8 .04 & 19 & 5100 & & & 3.04 & NM & & 0.46 & 43.7 & -13.7 & \\
\hline & EG11 & 15.1 .03 & 20 & 6200 & & & 1.77 & NM & & 1.07 & & & 1.2 \\
\hline \multirow[t]{3}{*}{5612} & EG15 & 16.1 .07 & WL & 1660 & 25 & 6.7 & 5.24 & NM & & 4.44 & $50.0 \pm 0.3$ & -10.4 & \\
\hline & EG15 & 19.11 .07 & WL & 1670 & & 6.4 & 4.45 & NM & & & & -9.5 & 1.2 \\
\hline & EG15 & 30.6 .04 & 10 & 4600 & & & 3.62 & NM & & & & & \\
\hline \multirow[t]{2}{*}{5613} & EG15 & 10.1 .07 & 19 & 6300 & 26 & 5.9 & 1.59 & NM & & 0.66 & $61.9 \pm 0.3$ & -15.4 & \\
\hline & EG15 & 19.11 .07 & 19 & 6300 & & 6.0 & 2.45 & NM & & & & & 1.8 \\
\hline
\end{tabular}


Appendix Carbon system parameters and isotope composition of springs and groundwater from the $\mathrm{DS}$ area. $(\mathrm{NM}=$ not measured; $\mathrm{BDL}=$ below detection limit; $\mathrm{TA}=$ total alkalinity; $\mathrm{DIC}=$ dissolved inorganic carbon; $\mathrm{WL}=$ water level). (Continued)

\begin{tabular}{|c|c|c|c|c|c|c|c|c|c|c|c|c|c|}
\hline RT- & $\begin{array}{l}\text { Sample } \\
\text { name }\end{array}$ & $\begin{array}{l}\text { Samp- } \\
\text { ling } \\
\text { date } \\
\text { (d.m.y) }\end{array}$ & $\begin{array}{l}\text { Depth } \\
(\mathrm{m})\end{array}$ & $\begin{array}{l}\mathrm{Cl} \\
(\mathrm{mmol} / \\
\left.\mathrm{kg} \mathrm{H}_{2} \mathrm{O}\right)\end{array}$ & $\begin{array}{l}\mathrm{T} \\
\left({ }^{\circ} \mathrm{C}\right)\end{array}$ & $\mathrm{pH}$ & $\begin{array}{l}\text { TA } \\
\text { (meq/ } \\
\text { L) }\end{array}$ & $\begin{array}{l}\mathrm{CH}_{4} \\
(\mathrm{mmol} / \\
\left.\mathrm{kg} \mathrm{H}_{2} \mathrm{O}\right)\end{array}$ & $\begin{array}{l}\delta^{13} \mathrm{C}_{\mathrm{CH} 4} \\
(\% 0 \\
\mathrm{PDB})\end{array}$ & $\begin{array}{l}\mathrm{DIC} \\
(\mathrm{mmol} / \\
\left.\mathrm{kg} \mathrm{H}_{2} \mathrm{O}\right)\end{array}$ & $\begin{array}{l}{ }^{14} \mathrm{C}_{\text {DIC }} \\
\text { (pMC) }\end{array}$ & $\begin{array}{l}\delta^{13} C_{\text {DIC }} \\
(\% o \\
\text { PDB })\end{array}$ & $\begin{array}{l}{ }^{3} \mathrm{H} \\
\text { (TU) }\end{array}$ \\
\hline & EG15 & 25.8 .04 & 19 & 6800 & & & 4.12 & NM & & 0.21 & 66.1 & -15.3 & \\
\hline & EG15 & 30.6 .04 & 20 & 7000 & & & 2.02 & NM & & & & & \\
\hline & EG16 & 7.3.07 & WL be & 1730 & 25 & 6.2 & 4.02 & 0.06 & & 3.44 & & -9.9 & \\
\hline \multirow[t]{4}{*}{5614} & EG16 & 7.3.07 & WL af & 2330 & 27 & 6.0 & 3.99 & 0.09 & & 3.29 & $46.8 \pm 0.2$ & -9.9 & \\
\hline & EG16 & 19.11 .07 & WL & 2780 & 30 & & 4.08 & NM & & & & -9.2 & 1.3 \\
\hline & EG16 & 25.8 .04 & 2.53 & 4000 & & & 3.63 & NM & & 0.47 & 55.4 & -9.7 & \\
\hline & EG16 & 22.12 .08 & 8 & & & & & BDL & -39.7 & 2.74 & & & \\
\hline \multirow[t]{4}{*}{5615} & EG16 & 7.3.07 & 11 & 6500 & 23 & 5.3 & 2.06 & NM & & 0.63 & $86.1 \pm 0.4$ & -10.2 & \\
\hline & EG16 & 19.11 .07 & 11 & 6900 & 27 & & 2.04 & NM & & & & & 2.9 \\
\hline & EG16 & 25.8 .04 & 11 & 7000 & & & 2.46 & NM & & 0.18 & 86.6 & -7.3 & \\
\hline & EG16 & 15.11 .04 & 12 & 7100 & & & 1.79 & NM & & & & & \\
\hline \multirow[t]{3}{*}{5714} & EG22 & 26.11 .07 & 25 & 6100 & 26 & 5.7 & 1.80 & 0.30 & & 1.80 & $51.4 \pm 0.3$ & -14.1 & 2.5 \\
\hline & EG22 & 22.12 .08 & 25 & & & & & 0.09 & -40.9 & & & & \\
\hline & EG22 & 19.11 .07 & 28 & 6700 & & & 1.80 & NM & & & & & \\
\hline \multirow[t]{11}{*}{5713} & EG20 & 26.11 .07 & 55 & 7000 & 23 & 5.6 & 2.06 & 0.25 & & 2.06 & $45.6 \pm 0.3$ & -17.0 & 1.8 \\
\hline & DS & 5.12 .07 & WL & 7100 & & & 4.55 & NM & & & & & 3.5 \\
\hline & DS & 9.5 .05 & WL & 7000 & & & 3.50 & NM & & 0.88 & & 2.8 & \\
\hline & DS & 2.6.03 & 15 & 7100 & & & 3.65 & NM & & 0.95 & 82.0 & 2.8 & 3.7 \\
\hline & DS & $1997^{\mathrm{a}}$ & & 7040 & & & 4.53 & & & & & & \\
\hline & DS & $1980^{\mathrm{a}}$ & WL & 7100 & & & & & & & & & \\
\hline & DS & $1980^{\mathrm{b}}$ & WL & & & & & & & & $86.9 \pm 1.5$ & & \\
\hline & DS & $1980^{\mathrm{b}}$ & WL & & & & & & & & $90.4 \pm 1.7$ & & \\
\hline & DS & $1977^{\mathrm{b}}$ & WL & & & & & & & & $107.7 \pm 1.6$ & & \\
\hline & DS & $1963^{c}$ & WL & & & & & & & & $82.7 \pm 0.5$ & & \\
\hline & DS & $1963^{\mathrm{c}}$ & WL & & & & & & & & $82.2 \pm 0.6$ & & \\
\hline
\end{tabular}

aYechieli and Arad 1997.

bTalma et al. 1997.

${ }^{\mathrm{c}}$ Neev and Emery 1967. 